\title{
TATA RUANG DAN PERKEMBANGAN KOMPLEKS PABRIK GULA TANJUNG TIRTO TAHUN 1920-1944, KABUPATEN SLEMAN
}

\author{
Spatial and Development of Tanjung Tirto Sugar Factory in 1920-1944, Sleman \\ Regancy
}

\author{
Oktavian Ardana Putra ${ }^{1)}$ dan Niken Wirasanti ${ }^{2)}$ \\ Universitas Gadjah Mada \\ Bulaksumur, Yogyakarta \\ 1) E-mail: oktavianardana76@gmail.com \\ ${ }^{2)}$ E-mail: wirasanti.niken@gmail.com
}

\author{
Naskah diterima: 01 Oktober 2019 Revisi terakhir: 07 November 2019 \\ Disetujui terbit: 05 Desember 2019 - Tersedia secara online: 17 Desember 2019
}

\begin{abstract}
The Tanjung Tirto sugar factory was one of 18 sugar factories that had been established in Yogyakarta during the Dutch East Indies administration. This factory was built in 1874 and was destroyed in the 1940s. The layout and development of the sugar factory from 1920-1940 were discussed in this study. Based on field observations, the emplacement of the factory buildings was not complete and only left a few housing buildings for the former factory employees. In addition, reconstruction through an old map is a way to find out the location and development of this factory. This study is important considering the lack of sugar factories in Yogyakarta which are the object of archeological research studies.
\end{abstract}

Keywords: Sugar factory, spatial planning, reconstruction

\begin{abstract}
Abstrak
Pabrik Gula Tanjung Tirto merupakan salah satu dari delapan belas pabrik gula yang pernah berdiri di Yogyakarta pada masa pemerintahan Hindia Belanda. Pabrik ini mulai dibangun pada tahun 1874 dan mengalami kehancuran memasuki tahun 1940-an. Tata ruang dan perkembangan pabrik gula dari tahun 1920-1940 menjadi bahasan dalam kajian ini.. Berdasarkan pengamatan di lapangan menunjukkan emplasemen bangunan pabrik sudah tidak utuh dan hanya menyisakan beberapa bangunan perumahan bekas pegawai pabrik tersebut. Selain itu, upaya rekontruksi melalui peta lama menjadi salah cara untuk mengetahui tata ruang dan perkembangan pabrik ini. Kajian ini menjadi penting mengingat masih minimnya pabrik gula di Yogyakarta yang dijadikan objek kajian penelitian arkeologi.
\end{abstract}

Kata kunci: Pabrik gula, tata ruang, rekonstruksi

\section{PENDAHULUAN}

Sejak diberlakukannya Undang-Undang Agraria pada tahun 1870 di Hindia Belanda, wilayah Jawa bagian tengah dan timur menjadi lokasi strategis bagi para investor dan pihak perkebunan swasta asal Eropa untuk mendirikan pabrik gula. Hal ini dikarenakan iklim dan kondisi lahan di Jawa bagian tengah dan timur sangat baik dan cocok untuk ditanami tebu sebagai bahan dasar gula. Salah satu wilayah yang cukup 
padat dengan keberadaan pabrik gula tersebut adalah wilayah Vorstenlanden ${ }^{1}$. Pada wilayah tersebut pusat-pusat perkebunan terdapat di daerah Klaten, Sukoharjo, sebagian Boyolali, dan Sragen yang merupakan bagian dari wilayah administrasi Kasunanan Surakarta dan untuk wilayah administrasi Kasultanan Yogyakarta terdapat di Sleman dan Bantul (Suhartono, 1995: 3).

Pabrik gula menjadi salah satu kajian yang cukup penting untuk arkeologi, terutama dalam kajian arkeologi industri. Kajian arkeologi industri didefinisikan sebagai studi tentang bukti-bukti yang menunjukkan perkembangan sosial, ekonomi dan teknologi sejak periode industrialisasi (Palmer dan Neaverson, 1998: 1). Arkeologi industri dapat dipahami sebagai usaha memamahami aktivitas industri di masa lampau melalui tinggalan materialnya (Inagurasi, 2010: 6).

Peran pabrik gula sebagai salah satu kajian ilmu arkeologi menjadi objek penting karena merupakan bukti nyata yang penting dalam sejarah perkembangan perekonomian masa lampau, khususnya berkaitan dengan sejarah perkebunan dan lahirnya industri gula di Nusantara, serta memiliki nilai penting sejarah lainnya yaitu merekam perkembangan teknologi pada masanya yang umumnya langsung diterapkan pada aktivitas industri di Hindia Belanda. Selain itu, bangunan pabrik gula juga memiliki nilai estetis berupa gaya arsitektur indis yang khas sebagai bangunan industri. Dengan demikian nilai penting dari bangunan-bangunan yang berada di kawasan pabrik gula ialah terletak pada nilai arsitektural dan historisnya(Inagurasi, 2010).

Penelitian ini menggunakan pendekatan keruangan (Spatial Analysis) skala meso. Skala meso mempelajari sebaran dan hubungan lokasi antara benda-benda arkeologi dan tata ruang suatu bangunan atau fitur (Mundardjito, 1995: 25). Data yang telah diidentifikasi kemudian dikorelasikan dengan peta topografi tahun 1926. Kemudian diklasifikasikan berdasarkan fungsinya yang bertujuan untuk mempermudah dalam melakukan analisis. Pabrik Gula Tanjung Tirto sebagai suatu situs yang terdiri atas beberapa bangunan (kompleks) yang memiliki fungsi masing-masing. Dari keletakan masing-masing bangunan tersebut akan diketahui pola tata ruang Pabrik Gula Tanjung Tirto. Korelasi komponen dan gambaran tata ruang Pabrik Gula Tanjung Tirto dikaji kembali dengan pendekatan sejarah untuk mengetahui perkembangan pabrik gula Tanjung Tirto.

\section{SEJARAH PABRIK GULA DI VORSTENLANDEN}

Dalam perkembangan sejarah perkebunan di Indonesia daerah Vorstenlanden (Surakarta dan Yogyakarta) mengalami beberapa sistem sewa tanah. Sistem sewa tanah inilah yang nantinya turut mempengaruhi tumbuhnya pabrik-pabrik gula di Vorstenlanden. Sebagai daerah kerajaan, Surakarta dan Yogyakarta awalnya diberlakukan sistem apanage stelsel. Sistem ini mewajibkan rakyat untuk menyerahkan

\footnotetext{
${ }^{1}$ Vosrtenlanden adalah istilah untuk menyebutkan daerah Kerajaan Yogyakarta dan Kerajaan Surakarta tahun 1799. Lihat Suhartono, "Apanage dan Bekel: Perubahan Sosial di Pedesaan Surakarta 1830-1920", 1991, hlm. 23.
} 
sebagian $1 / 2$ atau $1 / 3$ hasil dari tanahnya disamping menyerahkan tenaganya tanpa bayaran satu hari dalam seminggu. Rakyat hanya mengerjakan tanah seluas 4/5 dan sisanya $1 / 5$ dari luas tanah diberikan kepada bekel. Bekel bertugas sebagai pengawas dan pengelola rakyat dalam melaksanakan tugasnya (Mubyarto et al., 1992: 41).

Perkembangan perkebunan di daerah Vorstenlanden sangat pesat terutama perkebunan tebu. Di daerah Yogyakarta tercatat ada 11 perkebunan tebu dari 51 perkebunan yang ada dan 44 perkebunan tebu di daerah Surakarta dari 138 total perkebunan di daerah tersebut (Suhartono, 1995: 69). Berkembang pesatnya perkebunan tebu diikuti dengan munculnya pabrik gula di Vorstenlanden. Hingga tahun 1909 berdasarkan peta Kaart Der Suikerfabrieken Spooren Tramwegen van Java en Madoera tercatat sebanyak 18 pabrik gula yang beroperasi di Yogyakarta dan 15 pabrik gula yang beroperasi di daerah Surakarta.

Dengan potensi sumberdaya yang baik, daerah Vorstenlanden menjadi salah satu pengeskpor komoditi gula. Produksi gula di Yogyakarta tahun 1862 sebanyak 20.751 pikul kemudian meningkat menjadi 64.500 pikul pada tahun 1866, dan menjadi 492.625,75 pikul/tahun (Suhartono, 1995: 69). Hal sama juga terjadi di Surakarta, produksi komoditi ekspor tidak terpaut banyak dari Yogyakarta. Sebagai salah satu daerah penghasil komoditi ekspor yang tinggi dan perlu diangkut ke pelabuhan Semarang, NISM (Netherlandsch Indische Spoorweg Maatschappij) membuka jalur kereta api Semarang-Vorstenlanden (Tim Telaga Bakti Nusantara, 1997: 53).

Berdasarkan peta Kaart Der Fabrieken Spoor en Tramwegen tahun 1909 di wilayah Vosrtenlanden khususnya Kasultanan Yogyakarta diketahui terdapat 18 pabrik gula. Pabrik gula yang pernah beroperasi pada saat itu diantaranya PG Randoe Goenting, PG Tandjoeng Tirto, PG Wonotjatoor, PG Kedaton Pleret, PG Gesiekan, PG Rewoeloe, PG Klatjie, PG Demak Ijo, PG Beran, PG Medarie, PG Tjebongan, PG Bantool, PG Sedayoe, PG Gondang Lipuro, PG Sewoe-Galoor, PG Gesiekan, PG Poendong, dan PG Barongan. Banyaknya pabrik gula di wilayah ini, menandakan Kasultanan Yogyakarta menjadi salah satu wilayah industri gula terbesar di waktu itu. Memasuki tahun 1930, terjadi Krisis Malaise $^{2}$ yang memberikan dampak pada penurunan drastis pada ekspor permintaan pasar dunia untuk gula. Hal ini sangat berimbas pada kelangsungan pabrik-pabrik gula di Hindia Belanda pada saat itu.

Krisis ini mengakibatkan dilakukannya sistem kuota yaitu dengan membatasi produksi gula. Produksi gula di Jawa diwajibkan menurunkan jumlahnya dari 3 juta ton menjadi 1,4 juta ton per tahun. Akibatnya 9 dari 17 pabrik gula yang berada di Kasultanan Yogyakarta harus ditutup, sedangkan 8 pabrik gula diantaranya Pabrik Gula Tanjung Tirto, Pabrik Gula Kedaton Pleret, Pabrik Gula Medari, Pabrik Gula Cebongan, Pabrik Gula Beran, Pabrik Gula Gondang Lipura, Pabrik Gula Gesikan, dan Pabrik Gula Padokan tetap bertahan menghadapi krisis tersebut (Tim Penyusun, 2013).

\footnotetext{
${ }^{2}$ Malaise atau depresi ekonomi dunia merupakan meningkatnya produksi gula di beberapa negara yang yang biasanya mengimpor gula dan menurunnya impor gula oleh Inggris, Cina, dan Jepang sehingga harga gula mengalami terutama harga barang ekspor ke luar negeri. Lihat Mubyarto-Daryanti, "Gula: Kajian Sosial Ekonomi”, 1991, hlm. 11
} 


\section{Pabrik Gula Tanjung Tirto}

Salah satu pabrik gula yang berdiri wilayah Kasultanan Yogyakarta adalah Pabrik Gula Tanjungtirto (Sf. Tanjoengtirto). Beberapa peta kuna menyebutkan pabrik gula Tanjung Tirto sama dengan Pabrik Gula Kalasan. Pabrik ini didirikan pada tahun 1874 oleh orang Belanda yaitu Wieseman dan Broese van Groenau yang bekerjasama dengan Internationale Crediet en Handelsvereeniging "Rotterdam"(Internatio). Internatio merupakan perusahaan perbankan yang berkedudukan di Negeri Belanda dan telah berdiri sejak tahun 1863. Untuk menunjang operasional Pabrik Gula Tanjung Tirto, Internationale Crediet en Handelsvereeniging juga mendirikan beberapa bangunan sebagai fasilitas pendukung yang dibangun secara bertahap sejak tahun 1874 . Beberapa bangunan tersebut di antaranya adalah gedung kantor adminsistratur yang selesai dibangun tahun 1923, perumahan untuk ziender dan pegawai pribumi (19231924), bangunan rumah sakit pembantu (hulpziekenhuizen) (1922), dan bangunan sekolah pertukangan (ambachtschool) yang diresmikan tahun 1928 (Tim Penyusun, 2013).

Dalam perkembangannya, Pabrik Gula Tanjung Tirto mengalami beberapa pergantian administratur. Administratur yang pertama dijabat oleh G. A. S. Hempenius (1905-1908). Kemudian W. K. van Gennep menggantikan Hempenius dari tahun 1908 hingga 1912. Administratur berikutnya adalah W. Broese van Groenou menjabat tahun 1913-1923 dan dijadikan sebagai direktur tahun 1924. Pada tahun 1924 kekosongan administratuur diambil alih oleh G. L. Hovenkamp 1924 hingga 1929, Ir. O. Jansen van Raay (1929-1933) dan kemudian digantikan oleh F. Moorman tahun 1933 yang merupakan adminsitratur pabrik gula Bantul pada saat itu (Jong, 1930: 12).

Beberapa tinggalan bekas Pabrik Gula Tanjung Tirto yang hingga saat ini masih dapat dijumpai berupa beberapa bekas bangunan inti pabrik, bekas perumahan pegawai serta bekas fasilitas penunjang pabrik lainnya. Peralihan fungsi beberapa bangunan kompleks pabrik gula terjadi seiring dengan berhentinya operasi pabrik. Kondisi saat ini memperlihatkan beberapa bangunan kompleks pabrik beralih fungsi menjadi rumah warga, kantor polsek, serta menjadi tempat sarana pendidikan.

\section{SARANA DAN PRASARANA PENUNJANG PABRIK GULA}

\section{Sarana Penunjang Bekas Pabrik Gula Tanjung Tirto}

Menurut KBBI pengertian mengenai sarana adalah segala sesuatu yang dapat dipakai sebagai alat dalam mencapai maksud atau tujuan. Jika merujuk pada pada pengertian tersebut maka yang dimaksud dengan sarana penunjang pada pabrik gula meliputi bangunan inti operasional yaitu meliputi bagunan sebagai tempat produksi termasuk di dalamnya alat-alat serta bangunan setelah produksi berlangsung. Selain itu, jalur-jalur lori juga merupakan sebagai sarana penunjang utama dalam pra produksi dan setelah produksi. Kondisi saat ini memperlihatkan bahwa sarana penunjang pada bekas Pabrik Gula Tanjung Tirto sudah tidak dapat dijumpai. 
Kompleks inti Pabrik Gula Tanjung Tirto telah mengalami banyak perubahan. Sejak berdiri tahun 1874 hingga dibumingahuskan, kompleks inti pabrik mengalami perubahan fungsi maupun fisik. Beralihnya masa penjajahan dari Belanda ke Jepang turut mempengaruhi Pabrik Gula Tanjung Tirto. Pada masa kependudukan Jepang pabrik ini berhenti beroperasi dan beralih fungsi menjadi barak militer Jepang. Pada masa setelah kemerdekaan komplek inti pabrik dibumihanguskan oleh pribumi. Hal ini

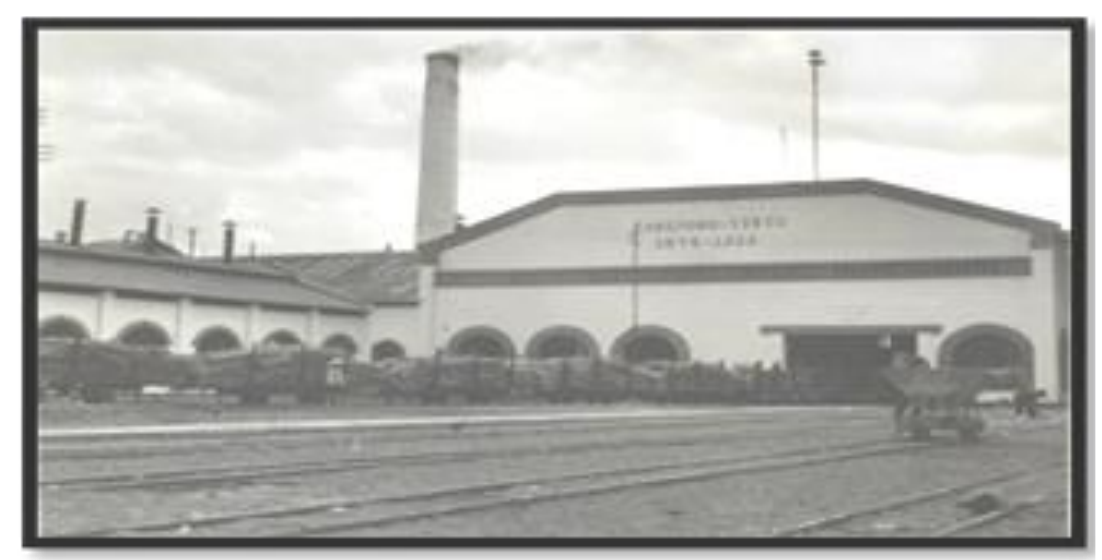

Gambar 1. Emplasemen PG. Tanjung Tirto Tahun 1937(Sumber: kitlv.nl diakses tahun 2017)

dilakukan untuk mencegah militer Belanda menggunakan kembali bangunan tersebut sebagai barak saat terjadi Agresi Militer Belanda ke-2 ${ }^{3}$. Bangunan inti Pabrik Gula Tanjung Tirto saat ini sudah tidak ada dan digantikan dengan bangunan pabrik pengeringan tembakau yang dibangun tahun 1957. Selain menjadi pabrik tembakau, bagian emplasemen pabrik telah berganti menjadi lapangan dan gedung TK.

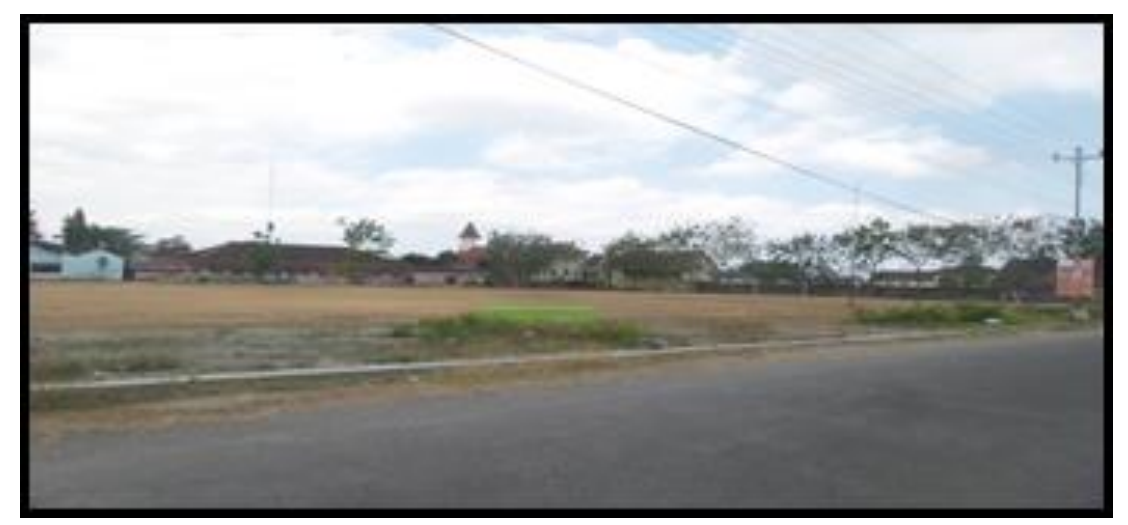

Gambar 2. Bekas bangunan inti operasional pabrik yang sekarang menjadi lapangan olahraga (Sumber: Dokumen Oktavian Ardana Putra, 2017)

\section{Prasarana Penunjang Bekas Pabrik Gula Tanjung Tirto}

Menurut KBBI pengertian mengenai prasarana adalah segala sesuatu yang merupakan penunjang utama terselenggaranya suatu proses (usaha, pembangunan proyek, dan sebagainya). Jika merujuk pada pengertian tersebut maka yang dimaksud

3 Wawancara oleh Oktavian Ardana Putra dengan narasumber Supomo (72 tahun). Wawancara dilaksanakan pada tanggal 2 Februari 2017. 
dengan prasarana penunjang bekas Pabrik Gula Tanjung Tirto merupakan bangunan fasilitas yang secara tidak langsung mempengaruhi kegiatan pra produksi hingga setelah produksi. Beberapa prasarana penunjang tersebut diantaranya adalah sebagai berikut:

\section{Bekas Perumahan Pegawai Pabrik Gula}

Bekas kompleks perumahan pegawai Pabrik Gula Tanjung Tirto saat ini memiliki kondisi yang berbeda. Perbedaan tersebut meliputi kondisi fisik bangunan maupun perubahan fungsinya. Beberapa bangunan tersebut telah beralih fungsi menjadi menjadi area sekolahan, kantor kepolisian, Koramil, serta menjadi hunian bagi keluarga mantan pegawai yang bekerja di Pabrik Gula Tanjung Tirto saat masih aktif beroperasi.

Bekas kompleks perumahan pegawai ini tersisa sepuluh bangunan yang letaknya dipisahkan oleh jalan desa yaitu tujuh berada di sebelah utara Jalan Tanjung Tirto sedangkan tiga lainnya berada di sebelah selatan. Dari kesepuluh bangunan tersebut enam di antaranya memiliki gaya bangunan yang relatif sama sedangkan empat lainnya memiliki gaya bangunan yang berbeda. Dalam struktur organisasi pabrik yang telah dikemukakan sebelumnya, menunjukkan adanya hirarki jabatan yang berbeda. Hal ini turut mempengaruhi perbedaan gaya arsitektur bangunan hunian bagi pekerjanya.

\section{Bekas Rumah Administratur}

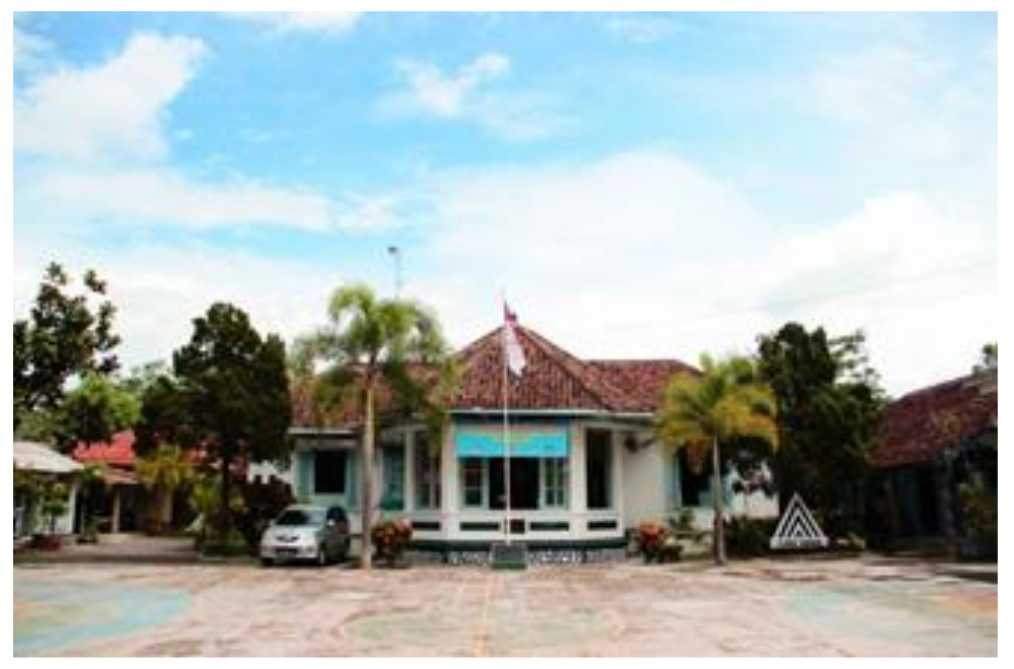

Gambar 3. Fasad bangunan induk SMP N 1 Berbah (Sumber: Dokumen Lanang Kurniajati, 2018)

Bekas rumah administratur saat ini digunakan sebagai kompleks Sekolah Menengah Pertama Negeri (SMP N ) 1 Berbah. Bangunan SMP N 1 Berbah secara administratif terletak di Dusun Teguhan, Desa Kalitirto, Kecamatan Berbah, Kabupaten Sleman. Lokasi bangunan ini berada di utara jalan Teguhan dan berdampingan dengan bangunan Polsek Berbah. Berdasarkan keletakkannya bangunan ini berada di sebelah utara bekas bangunan inti pabrik. Bangunan ini dibangun pada tahun 1923 oleh pendiri Pabrik Gula Tanjung Tirto yaitu Internationale Crediet en Handelsvereeniging (Internatio) yang berkedudukan di Rotterdam, Belanda. Bangunan ini awalnya 
digunakan sebagai rumah dinas administratur Pabrik Gula Tanjung Tirto (Tim Penyusun, 2013: 5). Dalam struktur kepegawaian pabrik gula, adminsitratuur menempati jabatan tertinggi. Dalam perkembangannya, bekas rumah adminstratur ini mengalami beberapa kali perubahan fungsi setelah Pabrik Gula Tanjung Tirto berhenti beroperasi. Setelah masa kemerdekaan yaitu tahun 1951 bangunan ini digunakan sebagai Sekolah Teknik Negeri (STN) Kalasan. Kemudian pada tahun 1969 STN Kalasan beralih fungsi menjadi SMP N 1 Berbah hingga sekarang (Tim Penyusun, 2013: 9). Sejak berlaih fungsi menjadi sekolahan, bangunan ini mengalami perubahan fisik termasuk bangunan asli (ruang kantor) dan adanya penambahan bangunan sebagai sarana penunjang kegiatan belajar mengajar.

\section{Bekas Rumah Ziender}

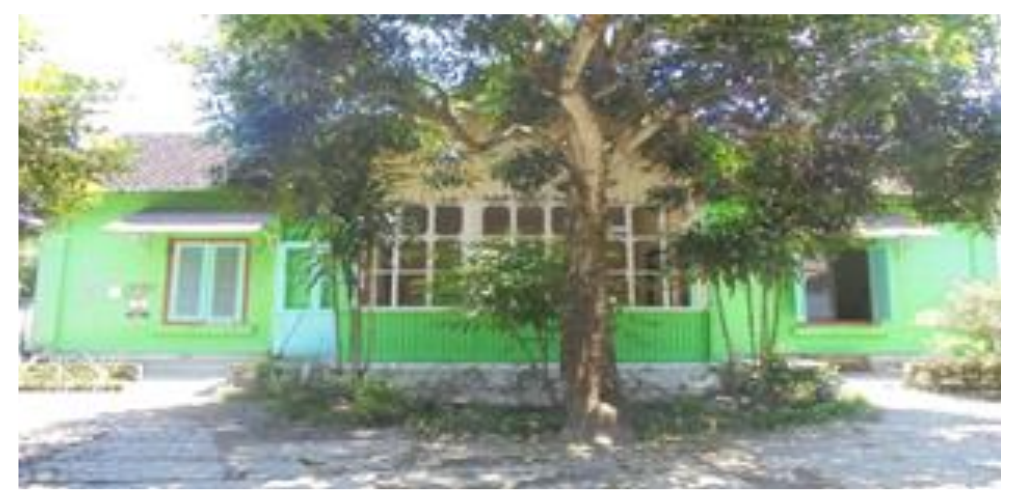

Gambar 4. Fasad Rumah Ny. Neti Gabeler (Sumber: Dokumen Oktavian Ardana Putra, 2017)

Bangunan rumah Ny. Neti Gabeler merupakan salah satu rumah peninggalan sisa Pabrik Gula Tanjung Tirto. Bangunan rumah ini berada di sebelah utara Jalan Tanjung Tirto dan menghadap ke selatan. Sebelum ditempati oleh Ny. Neti Gabeler, bangunan ini ditempati oleh Bapak Suwito Harjono. Beliau merupakan salah satu pegawai sinder (ziender) Pabrik Gula Tanjung Tirto saat itu ${ }^{4}$. Saat ini status kepemilikan rumah tersebut dipegang oleh Bapak Sujono yang merupakan cucu dari bapak Suwito Harjono sekaligus suami dari Ny. Neti Gabeler. Selain bangunan utama, bangunan rumah Ny. Neti memiliki bangunan yang berada di belakang. Menurut narasumber semua bangunan dan ruangan rumah tersebut masih asli termasuk bangunan yang ada di belakang. Bangunan belakang dengan bangunan inti dihubungkan oleh pintu dan anak tangga. Lantai bangunan ini lebih rendah dari pada bangunan sebelumnya. Atap pada bangunan ini berupa atap kampung. Bangunan bagian belakang ini menghadap ke barat. Ruangan bangunan belakang ini terdiri dari ruang dapur serta gudang.

\footnotetext{
${ }^{4}$ Wawancara oleh Oktavian Ardana Putra dengan narasumber Ny. Neti Gabeler. Wawancara dilakukan pada tanggal 2 Februari 2017.
} 


\section{Bekas Rumah Sakit Pembantu Tanjung Tirto}

Rumah Sakit Pembantu Tanjung Tirto didirikan pada tahun 1922 (Siswandi, 1989: 45). Rumah sakit ini merupakan cabang dari Rumah Sakit Petronela atau saat ini dikenal dengan Rumah Sakit Bethesda. Pembangunan rumah sakit ini diprakarsai oleh Rumah Sakit Bethesda yang bekerja sama dengan bank Internatio. Internatio sendiri merupakan pemodal utama bagi pembangunan Pabrik Gula Tanjung Tirto. Sebagai pihak pemodal yang utama, Internatio menginginkan adanya pelayanan kesehatan bagi para karyawan yang bekerja di pabrik gula serta penduduk sekitar. Hal ini ditunjukkan dengan kunjungan pasien yang rata-rata 50 pasien per hari (Siswandi, 1989: 45). Sebagian besar bangunan ini hancur setelah adanya gempa bumi pada tahun 2006. Pada tahun 2010 bekas rumah sakit pembantu ini berubah nama fungsi sebagai Puskesmas Berbah dan di bawah naungan Dinas Kabupaten Sleman.

\section{Sekolah Pertukangan Tanjung Tirto}

Sekolah pertukangan Tanjung Tirto (Ambachtsschool Tanjung Tirto) didirikan pada tanggal 15 Mei 1928. Peresmian bangunan ini ditandai dengan penanaman pohon beringin oleh Sri Sultan Hamengku Buwono VIII yang disaksikan oleh Paku Alam VII dan residen Yogyakarta (Tim Penyusun, 2013). Pembangunan sekolah pertukangan ini didirikan oleh pihak Internatio sebagai sarana penunjang Pabrik Gula Tanjung Tirto yang diperuntukkan bagi kaum pribumi. Sekolah ini membekali para kaum pribumi berupa ketrampilan meliputi perkayuan dan permesinan. Hal ini bertujuan menciptakan tenaga pekerja yang terampil dan siap diperkerjakan di Pabrik Gula Tanjung Tirto. Kondisi saat ini memperlihatkan bangunan sekolah pertukangan sudah tidak dapat dijumpai. Belum diketahui secara pasti letak berdirinya sekolah pertukangan ini.

\section{PEMBAHASAN}

Seperti yang sudah dijelaskan pada bab sebelumnya, untuk mengetahui pola tata ruang Pabrik Gula Tanjung Tirto digunakan pendekatan arkeologi ruang skala meso. Pendekatan ini mempelajari sebaran dan hubungan lokasional antara artefak-artefak dan fitur dalam suau situs (Clarke, 1997: 11-16 dalam Mundardjito, 1995: 25). Keletakan dari bangunan-bangunan di kompleks pabrik gula tersebut membetuk suatu pola tata ruang yang mencirikan tempat aktivitas adanya industri pabrik. Pemolaan keruangan dari situs-situs arkeologi dapat mencerminkan pemolaan manusia masa lalu yang didasarkan atas satu atau kumpulan pertimbangan teknologis ekologis, pertimbangan perilaku sosal, dan pertimbangan ideologis (Schiffer 1972: 156 dalam Mundardjito, 1995: 27).

Tahap analisis di sini menggunakan peta topogarfi tahun 1926 sebagai sarana proses identifikasi mengingat saat ini Pabrik Gula Tanjung Tirto sudah tidak beroperasi. Peta topografi tahun 1926 dinggap relevan untuk mengidentifikasi kelompok bangunan. Dari penelusuran yang penulis lakukan, peta topografi tahun 1926 menunjukkan bahwa emplasemen pabrik sudah dipetakan secara menyeluruh. Identifikasi bangunan pabrik 
ini nantinya akan dikorelasikan dengan hasil observasi di lapangan, wawancara maupun studi literatur.

\section{Pola Keletakkan Bangunan}

\section{- Aspek Fungsional}

Sebagai tempat industri, pabrik gula memerlukan berbagai sarana maupun bangunan yang digunakan untuk menunjang proses produksinya. Seperti pada umumnya, pabrik gula memerlukan beberapa tahap proses produksi untuk menghasilkan gula yang akan dipasarkan. Tahap-tahap tersebut diantaranya melalui proses pra produksi, produksi, hingga pasca produksi. Hal ini jamak dijumpai di beberapa pabrik gula masa Hindia Belanda yang sempat berdiri. Peta topografi tahun 1926 memberikan gambaran mengenai lokasi kompleks Pabrik Gula Tanjung Tirto secara meneyeluruh. Kompleks pabrik tersebut terbagi menjadi dua yaitu berada disisi utara dan sisi selatan jalan Tanjung Tirto. Pembungihangusan yang dilakukan oleh penduduk setempat pada masa agresi militer Belanda kedua membuat bangunan inti operasional pabrik rata dengan tanah. Untuk mengatasi keterbatasan data tersebut, hasil wawancara dan studi literatur dijadikan pedoman untuk melacak sekaligus menginterpretasikan data yang ada yaitu peta topografi tahun 1926.

Hasil wawancara menunjukkan bahwa letak bangunan inti operasional pabrik tersebut berada disisi sebelah selatan Jalan Tanjung Tirto (lihat denah Pabrik Gula Tanjung Tirto tahun 1926) $)^{5}$ tepat berada di depan kompleks perumahan pegawai Tanjung Tirto yang membujur dari barat ke timur. Peta topografi tahun 1926 menunjukkan, area bangunan inti operasional pabrik memiliki pola keletakkan yang memusat. Bangunan inti operasional ditunjukkan dengan adanya gambar cerobong asap (lihat denah Pabrik Gula Tanjung Tirto tahun 1926). Pada sisi sebelah timur bangunan tersebut berdiri beberapa bangunan yang merupakan bangunan penunjang bangunan inti operasional pabrik. Bangunan-bangunan yang berdiri di dekat bangunan inti operasional pabrik diasumsikan sebagai tempat untuk proses produksi hingga tahap pasca produksi.

Selain itu dalam peta topografi tahun 1926 tersebut menunjukkan adanya jaringan rel lori yang terputus dan menuju area dimana bangunan operasional itu berdiri (Lihat denah Pabrik Gula Tanjung Tirto tahun 1926). Observasi yang dilakukan di lapangan tidak dijumpai data material jaringan lori yang masih tersisa. Lori mempunyai peran penting dalam proses pra produksi hingga setelah produksi. Pada pra produksi lori berfungsi sebagai sarana transportasi untuk mengangkut tebu dari perkebunan menuju lokasi produksi sedangkan pada proses setelah produksi lori berperan mendistribusikan hasil pengolahan tebu ke stasiun dan diteruskan ke tempat tujuan. Pada umumnya lori berbentuk gerobak yang ditarik oleh lokomotif uap. Dengan demikian adanya data jaringan lori tersebut menguatkan adanya proses produksi di area tersebut.

\footnotetext{
${ }^{5}$ Wawancara dilakukan oleh Oktavian Ardana Putra dengan Narasumber Bapak Supomo (72 tahun). Wawancara dilakasanakan pada tanggal 2 Februari 2017.
} 


\section{- Aspek Hirarki Keruangan}

Bekas kompleks perumahan pegawai merupakan suatu kompleks yang terdiri dari bangunan perumahan pegawai yang bekerja di pabrik. Berdasarkan keletakannya, bekas kompleks ini terbagi atas perumahan pegawai staff tinggi, pegawai staf menengah dan pegawai staff rendah (buruh). Bekas kompleks perumahan pegawai staf tinggi berada disisi sebelah utara dari jalan Tanjung Tirto dan bangunan operasional pabrik. Kompleks bangunan ini mengelompok berderet dari barat ke timur, sedangkan kompleks perumahan pegawai staf rendah (buruh) mengelompok disisi sebelah selatan Jalan Tanjung Tirto (Lihat denah Pabrik Gula Tanjung Tirto tahun 1926)

Kompleks perumahan staf tinggi merupakan hunian yang diperuntukkan bagi karyawan pabrik dengan jabatan struktural yang lebih tinggi dibandingan dengan buruh. Data yang diperoleh dari studi literatur maupun di lapangan menunjukkan bahwa tujuh deretan rumah-rumah yang berada disisi sebalah utara jalan Tanjung Tirto terdiri dari satu bekas rumah administratur (pegawai staf tinggi) sedangkan enam lainnya merupakan bekas rumah pegawai staf menengah Pabrik Gula Tanjung Tirto (Lihat denah Pabrik Gula Tanjung Tirto tahun 1926). Rumah adminsitratur berdiri diapit oleh rumah-rumah pegawai staf menengah. Sebagai seorang pimpinan pabrik, adminisitratur termasuk dalam struktur pegawai staf tinggi. Letak rumah yang berada tepat di depan bangunan inti operasional sangat memungkinkan bagi adminstratur memiliki fungsi untuk mengawasi para pekerja dalam proses pra produksi hingga pasca produksi.

Pegawai staf menengah Pabrik Gula Tanjung Tirto meliputi sinder (Ziender), chemicer, machinist, juru masak pabrik, operasional jembatan timbang, pembantu operasional, bagian pembukuan (Golberg, 1940: 148). Jabatan administratur dan pegwai staf menengah masing-masing diisi oleh orang Belanda. Keberadaan checimer dan machinist dapat dilihat dari betuk arsitektural dari rumah sinder yang memiliki gaya arsitektural yang sama dengan enam bangunnya lainnya yang berada di sisi sebelah utara. Kondisi saat ini menunjukkan telah terjadi peralihan fungsi, bekas rumah pegawai staf menengah menjadi hunian warga sedangkan bekas rumah administratur beralih fungsi menjadi kompleks sekolahan.

Kompleks perumahan staf rendah (buruh) terletak disisi selatan jalan Tanjung Tirto. Seperti halnya kompleks inti bangunan operasional, kompleks bangunan perumahan staf rendah saat ini sudah tidak dapat dijumpai. Pada peta topografi tahun 1926 menunjukkan bahwa keletakan kompleks perumahan staf rendah mengelompok disisi barat bangunan inti operasional pabrik dan sisi selatan jalan Tanjung Tirto. Kompleks ini ditempati oleh para buruh yang bekerja Pabrik Gula Tanjung Tirto. Dalam struktur organisasi suatu pabrik gula pada masa Hindia Belanda, struktur paling bawah ditempati oleh mandor (overseer) dan buruh (employer). Mandor dan buruh merupakan pekerja dari kaum pribumi. Dalam kaitannnya dengan industri gula, buruh dibedakan menjadi dua yaitu buruh lapangan dan buruh pabrik. Buruh lapangan diawasi oleh sinder sedangkan buruh pabrik diawasi oleh chemicer dan machinist (Inagurasi, 2010). Mandor sendiri bertugas dalam mengawasi buruh tani yang bekerja di perkebunan tebu. Letaknya yang berada di selatan jalan memperlihatkan adanya pola pemisahan antara 
kompleks pegwai staf rendah, pegawai staf menengah, dan pegawai staf tinggi. Hal ini didasari oleh perbedaan status sosial maupun berdasarkan struktur jabatan di pabrik gula Tanjung Tirto.

Struktur Organisasi Pabrik Gula Tanjung Tirto Tahun 1874-1940 (Jong, 1930: 12).

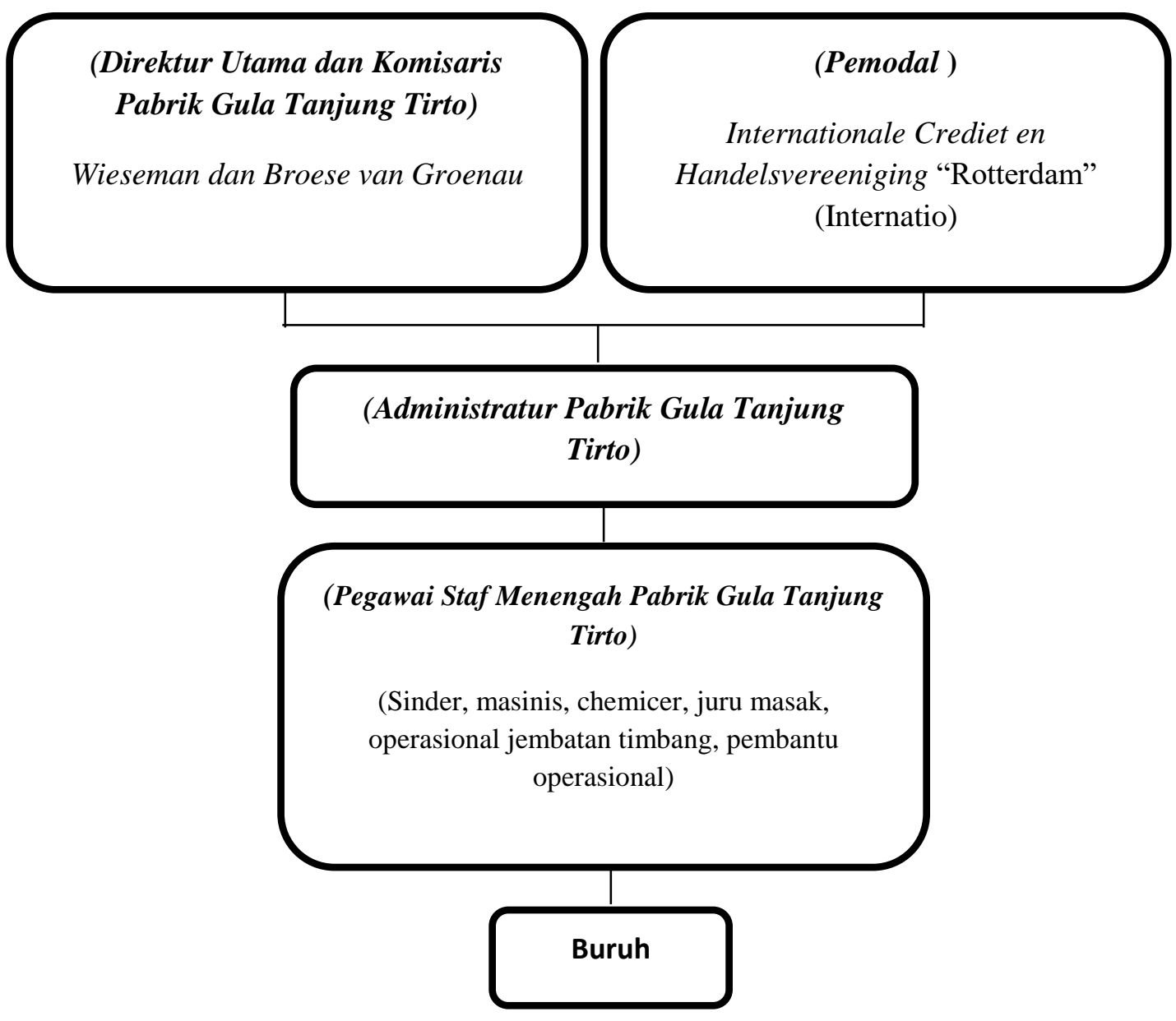

\section{Perkembangan Pabrik Gula Tanjung Tirto Tahun 1923-1940}

- Pabrik Gula Tanjung Tirto Tahun 1920

Pabrik gula Tanjung Tirto berdiri pada tahun 1874. Karena keterbatasan data berupa peta kuna saat awal berdirinya pabrik tersebut maka digunakan peta tahun 1920 sebagai data awal dalam menentukan proses perkembangan pabrik gula tersebut. Peta kuna tahun 1920 masih sangat relevan untuk menggambarkan keadaan awal Pabrik Gula Tanjung Tirto yang mulai dibangun pada tahun 1874 dan selesai dibangun pada tahun 1922. Hal ini mengingat belum terlihatnya perkembangan kompleks emplasemen pabrik yang signifikan. 


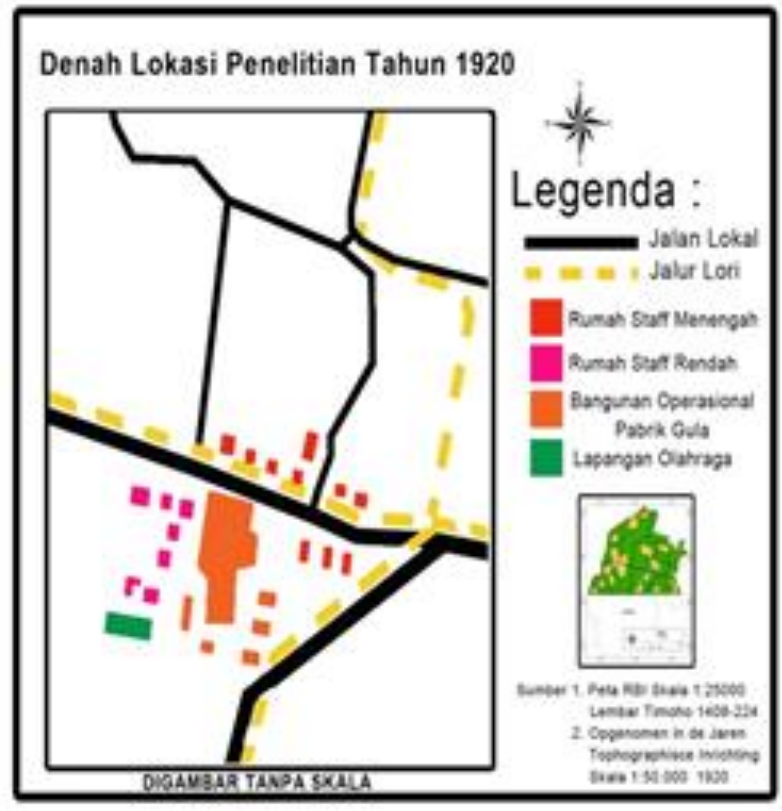

Gambar 5. Denah situasi lokasi pabrik pada tahun 1920 (Sumber: Dokumen Oktavian Ardana Putra, 2017)

Pada peta tahun 1920 menunjukkan kompleks awal berdirinya Pabrik Gula Tanjung Tirto. Pada tahun ini, kompleks pabrik gula dipisahkan oleh jalan desa Tanjung Tirto yaitu berada di sisi utara dan selatan. Kelengkapan sarana dan prasarana mulai terlihat seperti jaringan rel kereta lori (decauville), bangunan inti pabrik, serta sebagian bangunan bagi karyawan pabrik. Berkembangnya Pabrik Gula Tanjung Tirto tidak terlepas dari adanya perubahan sistem politik yang dilakukan oleh Pemerintah Hindia Belanda pada waktu itu. Berakhirnya sistem tanam paksa digantikan dengan munculnya Undang-Undang Agraria (Agrarische Wet) dan Undang-Undang Gula (Suiker Wet) tahun 1870. Kebijakan ini muncul menyusul adanya protes yang dilayangkan oleh kaum borjouis di negeri induk Belanda atas keprihatinan dengan adanya kebijakan tanam paksa yang menyengsarakan rakyat di tanah jajahan.

Kebijakan agararia ini berpengaruh pada berkembang pesatnya perkebunan swasta dan pabrik gula di Hindia Belanda. Bedirinya Pabrik Gula Tanjung Tirto tidak terlepas atas kebijakan yang diterapkan melalui Undang-Undang Agraria dan UndangUndang Gula tahun 1870. Kebijakan ini berpengaruh terhadap berkembang pesatnya perkebunan swasta dan pabrik gula di Hindia Belanda. Undang-Undang Agraria memberi kebebasan kepada pihak swasta untuk membuka perkebunan dengan menyewa tanah pribumi terutama untuk ditanami tanaman keras, sedangkan Undang-Undang Gula (Suiker Wet) merupakan kebijakan tentang pelarangan pengangkutan tebu keluar dari Indonesia. Sebelum tebu dikirim dan dipasarkan ke Belanda, tebu harus di ekstrak dan diproduksi di Indonesia 
- Pabrik Gula Tanjung Tirto Tahun 1926

Perkembangan Pabrik Gula Tanjung Tirto pada tahun ini terlihat berkembang dengan pesat. Kompleks emplasemen pabrik gula menunjukkan adanya penambahan bangunan sarana penunjang pabrik. Penambahan tersebut meliputi bangunan karyawan staf rendah (sisi barat bangunan inti pabrik), kompleks bangunan karyawan staf menengah (sisi utara jalan), bangunan kayawan staf tinggi (administratuur) serta munculnya Rumah Sakit Pembantu Tanjung Tirto yang berada disisi barat di luar kompleks pabrik serta fasilitas penunjang lainnya.

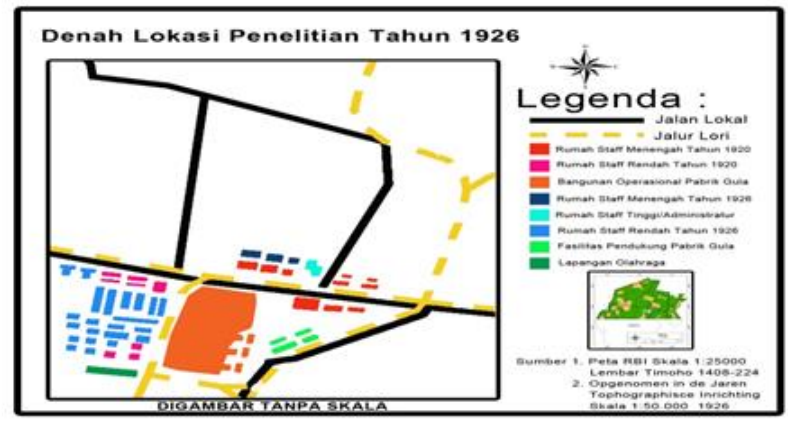

Gambar 6. Denah situasi lokasi pabrik pada tahun 1926 (Sumber: Dokumen Oktavian Ardana Putra, 2017)

Pada kurun waktu 1905 hingga 1924 produksi gula di Pabrik Gula Tanjung Tirto meningkat pesat. Hingga tahun 1923 keuntungan dari hasil produksi gula mencapai 10,75 gulden (Archief voor de Suikerindustrie in Ned-Indie, 1945 dalam Utama, 2017). Pada tahun 1926 produksi gula yang dihasilkan mencapai 155 kuintal/ha dan terus meningkat mencapai 210 kuintal/ha pada tahun 1929 (Jong, 1930: 35). Selain berupaya meningkatkan jumlah produksi, jajaran manajemen Pabrik Gula Tanjung Tirto turut menganggarkan dana sosial bagi kesejahteraan pekerjanya maupun penduduk sekitar. Hal ini terlihat dari anggaran tahun 1919 hingga 1929 pihak manajemen menganggarkan dana sosial hingga $f$ 190.264.74 untuk pembangunan lapangan olah raga, ruang relaksasi, rumah sakit pembantu, sekolah pertukangan serta yayasan sekolah Belanda-pribumi (Jong, 1930: 57-80). Anggaran tersebut juga merambah pada penambahan perumahan bagi karyawan kelas menengah (sinder), perumahan bagi pribumi yang selesai tahun 1924 dan rumah administratur tahun 1923 (Tim Penyusun, 2013).

Kebijakan ini berdampak pada bertambahnya area perkebunan maupun peningkatan produksi gula di berbagai perusahaan pabrik gula termasuk Pabrik Gula Tanjung Tirto. Untuk memenuhi permintaan pemerintah Hindia Belanda, Pabrik Gula Tanjung Tirto mengembangkan pembangunan sarana dan prasarana penunjang pabrik gula. Pihak manajemen mengambil langkah memperluas area emplasemen pabrik dengan membangun berbagai macam sarana prasarana pengembangan bangunan pada tahun ini tampak jelas jika dibandingkan dengan emplasemen pabrik pada tahun 1920. 


\section{- Pabrik Gula Tanjung Tirto Tahun 1940}

Perjanjian Kalijati memiliki peran penting dalam perpindahan kekuasaan dari pemerintahan Hindia Belanda ke Jepang. Sebelum perjanjian ini dilaksanakan telah terjadi peperangan di beberapa wilayah seperti Subang, Ciater, dan pelabuhan Kalijati. Untuk menghindari jatuhnya korban yang lebih banyak, Jepang berinisiatif melakukan perundingan dengan pihak pemerintah Hindia Belanda di Kalijati tahun 1942. Dalam perundingan itu pemerintah Belanda diwakili oleh Jenderal Ter Poorten sedangkan pihak militer Jepang diwakili oleh Panglima Imamura. Hasil dari perundingan tersebut pemerintah Hindia Belanda menyerahkan hak dan legitimasi wilayah jajahannya kepada Jepang.

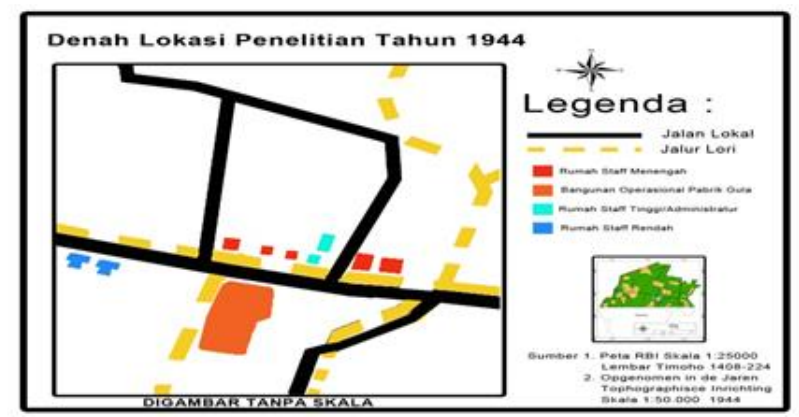

Gambar 7. Denah situasi lokasi pabrik pada tahun 1944 (Sumber: Dokumen Oktavian Ardana Putra, 2017)

Secara de facto dan de jure pemerintah Jepang secara resmi telah mendapatkan wilayah jajahannya di Indonesia dari tangan Belanda. Perpindahan kekuasan kolonial mempengaruhi arah kebijakan politik dan berpengaruh pada keberlannjutan perkebunan di indonesia. Selama kependudukan Jepang, terjadi penurunan produksi di sektor perkebunan terutama tanaman keras (kopi, tebu, teh, dan indigo). Kebijakan pemerintah Jepang yaitu membatasi penggunaan lahan rakyat yang awalnya ditanami tanaman keras digantikan dengan tanaman pangan (Mundardjito, 1995: 24). Peningkatan penanaman tanaman pangan ini ditujukan untuk kepentingan ekonomi perang.

Depresi ekonomi yang terjadi tahun 1931 berdampak pada kelangsungan Pabrik Gula Tanjung Tirto. Meskipun pabrik ini masih bertahan menghadapi depresi ekonomi tersebut namun pabrik ini mengalami penyusutan area perkebunannya sehingga berdampak terhadap jumlah produksi. Hingga tahun 1924 pabrik ini mempunyai area perkebunan seluas 1056.90 ha. Memasuki tahun 1940 area perkebunan Pabrik Gula Tanjung Tirto mengalami penurunan dan menyisakan area seluas 685 ha (Golberg, 1940: 148). Hal ini diperparah dengan berubahnya arah kebijakan perkebunan setelah Jepang menguasai Indonesia tahun 1942.

Kenampakan fisik area kompleks pabrik pada tahun 1944 mengalami perubahan yang cukup signifikan. Pabrik Gula Tanjung Tirto yang sudah tidak beroperasi beralih fungsi menjadi barak militer bagi tentara Jepang ${ }^{6}$. Selain itu, kompleks perumahan yang

\footnotetext{
${ }^{6}$ Wawancara dilakukan oleh Oktavian Ardana Putra dengan narasumber Bapak Supomo (72 tahun). Wawancara dilaksanakan pada tanggal 2 Februari 2017
} 
awalnya dihuni oleh para pegawai pabrik staf rendah sudah tidak dijumpai. Pada tahun ini beberapa fasilitas yang masih berdiri diantaranya adalah beberapa perumahan pegawai staf rendah, perumahan pegawai staf menengah dan bawah.

\section{SIMPULAN}

Unsur fisik emplasemen Pabrik Gula Tanjung Tirto mengalami perkembangan secara bertahap dari tahun 1920 hingga 1940. Dinamika yang terjadi ini tidak terlepas dari beberapa faktor diantaranya faktor internal dan eksternal. Faktor internal yaitu adanya upaya peningkatan jumlah produksi gula yang dilakukan oleh direksi pabrik, sedangkan faktor eksternal dipengaruhi oleh arah kebijakan politik dari pemerintah Hindia Belanda dan Pemerintah Jepang mengenai perkebunan masa itu. Selain itu, faktor dinamika ekonomi dunia turut mempengaruhi pasang surut produksi gula di Pabrik Gula Tanjung Tirto.

Berdasarkan keletakannya, bangunan inti Pabrik Gula Tanjung Tirto berpola memusat yang didasari oleh faktor fungsional. Gedung pabrik yang merupakan pusat produksi pengolahan tebu berdampingan dengan kompononen bangunan kelengkapan operasional pabrik sedangkan perumahan pegawai berpola mengelompok berdasarkan faktor jabatan struktural.

\section{DAFTAR PUSTAKA}

Golberg, J. H. (1940). Handboek de Suiker. Soerabaia: Uitgevers Maatschappij.

Inagurasi, L. H. (2010). Pabrik Gula Cepiring Kendal, Jawa Tengah 1830-1930: Sebuah Studi Arkeologi. Universitas Indonesia.

Jong, W. M. de. (1930). Gedenkboek Ter Herinnering Aan Het 25-Jarig Bestaan Der N.V. Suikerfabriek Tandjoeng Tirto. Den Haag.

Mubyarto, Soetrisno, L., Setiawati, I., Sulistya, Djatmiko, E., Rejeki, N. S., ... Sumartoyo. (1992). Tanah dan Tenaga Kerja Perkebunan. Yogyakarta: Aditya Media.

Mundardjito. (1995). Kajian Kawasan: Pendekatan Strategis dalam Penelitian Arkeologi Indonesia Dewasa Ini. Berkala Arkeologi, Tahun XV Edisi Khusus (Manusia Dalam Ruang: Studi Kawasan dalam Arkeologi).

Palmer, M., dan Neaverson, P. (1998). Industrial Archaeology: Principles and Practice. London: Routledge.

Siswandi. (1989). Rumah Sakit Bethesda: Dari Masa ke Masa. Yogyakarta: Andi Offset.

Suhartono. (1995). Bandit-bandit Pedesaan di Jawa (Studi Historis: 1850-1942). Yogyakarta: Aditya Media.

Tim Penyusun. (2013). Laporan Pendataan Bangunan SMP N I Berbah dan Bangunan Kantor Polsek Berbah, Sleman. Yogyakarta. 
JURNAL PANALUNGTIK - Vol. 2, No. 2, Desember 2019

Tim Telaga Bakti Nusantara. (1997). Sejarah Perkeretaapian Indonesia Jilid 2. Bandung: Angkasa.

Utama, D. I. (2017). Pemogokan Buruh Pabrik Gula Tanjung Tirto Tahun 1918. Universitas Negeri Yogyakarta. 